\title{
Verslag oor die Internasionale Simposium, beter bekend as Taung 60, en Taung-Diamantjubileum
}

\author{
A. Spies \\ Derdelaan 47, Boston 7530
}

Hierdie simposium is gehou aan die Universiteit van die Witwatersrand, Johannesburg, asook die Universiteit van Bophuthatswana, Mmabatho, vanaf 27 Januarie tot 4 Februarie 1985. Alle reëlings is dan ook gesamentlik deur hierdie twee universiteite waargeneem onder die uiters bekwame leiding van professor P.V. Tobias en sy komitee van spesialiste.

\section{INLEIDENDE DOELSTELLINGS}

Die hoofdoel van die simposium was om die 60ste verjaarsdag van die Taung-skedelvonds en die aankondiging daarvan op 3 Februarie 1925 in die Johannesburgse Star en op 7 Februarie 1925 in Nature, Londen, te gedenk. Daarby is hulde gebring aan emeritus professor Raymond Dart vir sy reusebydrae en onderskeiding. Professor Dart kon saam met sy eggenote die simposium as Hoofbeskermheer bywoon. Die afsluitingsfunksie, 'n buffet-ete, het plaasgevind op 4 Februarie, die 92ste verjaarsdag van professor Dart.

Geen beter hulde kon aan die professor gebring word nie as juis 'n waardebepaling van wat alles sedert 1925 in die Paleoantropologie plaasgevind het, om kennis te neem van presies waar die besondere dissipline vandag staan en om die vooruitsigte te ondersoek vir toekomstige evolusionêre studies van hominide.

\section{LESINGS}

Die indeling van formele referate, waarvan daar meer as $\mathbf{5 0}$ was, is hoofsaaklik op geografiese basis gemaak, alhoewel daar sessies was oor meer algemene onderwerpe en ook oor toekomstige rigtings en horisonne. Ek verwys na enkeles:

\section{TANDMORFOLOGIE EN DIE SISTEMATIESE AFFINITEITE VAN DIE TAUNG- \\ HOMINIDE-FOSSIEL - F.E. GRINE (V.S.A.) \\ Volgens Grine toon die tandgetuienis van die Taung-skedel onweerlegbare ooreenkoms met dié van die australopiteke van Makapansgat, Laetoli en Hadar en word hulle sodoende onderskei van die meer robuuste australopiteke van Kromdraai en Swartkrans en dus ook van $A$. boisei.}

\section{VERDERE POGINGS TOT} OUDERDOMSBEPALING VAN DIE

TAUNG-TUFAS - J. VOGEL (S.A.)

Die datums wat onlangs aangekondig is vir die ouderdom van Taung-tufas is verrassend jonger as wat verwag is, maar streng gesproke blyk dit meer van toepassing te wees op die uraan-isotope in monsters en nie noodwendig op die kalktufas nie.

\section{IS AUSTRALOPITHECUS AFRICANUS VOORVADERLIK VIR HOMO? -}

M. McHENRY (V.S.A.)

Denkbeeldige voorvaders is gerekonstrueer uit eienskappe van $A$. robustus, $A$. boisei en $H$. habilis. Dit is gedoen met die veronderstelling dat hierdie hominides kontemporère spesies is wat 'n gemeenskaplike voorvader moes gehad het. 33 skedel- en tand-eienskappe is geidentifiseer as dieselfde in $H$. habilis, $A$. robustus en $A$. bosei, maar nie in een ander hominide nie. Van die ander hominides is $A$. africanus egter veel nader aan die veronderstelde voorvader as $A$. afarensis. In 'n verdere 9 trekke is $H$. habilis en $A$. africanus dieselfde, maar verskil $A$. afarensis, $A$. robustus en $A$. bosei. Hiervolgens wil dit dus lyk of $A$. africanus die naaste aan die onmiddellike voorvader is. Ook is dit moontlik dat die onmiddellike voorvader van Homo nog soek is.

\section{AUSTRALOPITHECUS AFARENSIS: TWEE GESLAGTE OF TWEE SPESIES? -}

\section{A.L. ZIHLMAN (V.S.A.)}

Hieruit blyk o.a.: Die getuienis van geslagtelike dimorfisme in lewende groot ape, tesame met data oor die basikraniale deel van die skedel, patrone van veneuse dreinering en ledemaat-beenmorfologie van die Hadar-hominides laat die vraag ontstaan of al daardie fossielmateriaal wel een spesie kon wees of voorvaderlik vir al die hominides kon wees.

\section{EKSKURSIES NA BEKENDE GROTTE Sterkfontein}

Hierdie bekende grot het ekstensiewe dolomitiese kalksteenneerslae wat in 1936 die eerste volwasse australopiteek-kranium opgelewer het. Sedertdien het geblyk dat dit een van die rykste terreine van vroee hominide-fossiele in Afrika is. Die bekende dr. Broom het baie werk hier gedoen, waar ook die kranium bekend as , mev. Ples" gevind is.

Vanaf 1968 is hier 320 hominide-monsters herwin, asook 2500 serkopiteek-fragmente en 'n baie groot verskeidenheid ander diersoorte, soos die drietoonperd (Hipparion). Ook is 'n kopbeen van $H$. habilis gevind en meer as 215 stukkies gefossileerde houttakkies. Professor Tobias self het hier as gids opgetree en dit was vir elkeen ' $n$ belewenis om na hierdie sjar- 
mante spreker en kenner te kon luister; daar is by hom geen gebrek aan woordeskat, gevatheid of die fynste nuansering van woord of gedagte nie.

\section{Swartkrans}

Ons was die gaste van dr. C.K. Brain, wat baie jare hier gewerk het. Swartkrans is 'n ryk bron van robuuste australopiteke. Tafonomiese interpretasie van die fossiele-versameling dui sterk daarop dat die hominide-fossiele die kosoorblyfsels verteenwoordig van groot katte wat hierdie grot opgesoek het as skuilplek en eetplek.

\section{Kromdraaj}

Die grot is $1,5 \mathrm{~km}$ oos van Sterkfontein geleë. In 1938 kom hierdie terrein in die nuus met die ontdekking deur Broom van 'n australopiteek-skedel en ook los tande. Gou was dit duidelik dat hierdie fossiel deurgaans growwer as die lenige $A$. africanus is, en die volgende spesie, Africanus robustus, word as fossiel gebore.

'n Kenmerkende verskynsel van die fossiele monsters ontdek deur Broom en Brain by Kromdraai, is die hoë persentasie van jeugdige primate. Die moontlikheid dus van 'n gelukkige ontdekking van 'n jeugdige $A$. robustus-skedel vir vergelyking met die bekende jeugdige Taung-skedel, is iets om na uit te sien. Die interessante Kromdraai mag selfs nog ander vondste oplewer wat meer lig kan werp op vroeë hominide-evolusie.

\section{DIE UNIVERSITEIT VAN BOPHUTHATSWANA}

Die lesings is op Saterdag, 2 Februarie, die oggend en middag by die Universiteit van Bophuthatswana voortgesit, waarvan ek 'n paar noem:

1. LAAT GEEN STEEN ONAANGEROERD: ARGEOLOGIESE VOORUITGANG EN KULTURELE INTERPRETASIES? J. DESMOND CLARK (V.S.A.)

2. PATRONE VAN KRANIALE DIVERSITEIT IN VROEË HOMINIDES VAN AFRIKA A. BILSBOROUGH (ENGELAND)

3. EVOLUSIE VAN DIE BOONSTE LUGWEË
VAN DIE HOMINIDES - J. LAITMAN

(V.S.A.)

\section{TAUNG-EKSKURSIE}

Op 3 Februarie het ons om 10h45 aangekom by die Buxton Limeworks, Pk. Norlim, Taung. Daar word natuurlik nie meer kalk gemyn nie. Hierdie terrein van die geskiedkundige Taung-skedel-ontdekking is sowat $9,6 \mathrm{~km}$ suidwes van die dorpie Taung en $130 \mathrm{~km}$ noord van Kimberley. Taung lê heelwat suid van die Moloporivier. Taung beteken die plek van die Leeu (Tau). Tau was die hoof van die Leghoya of Bataung wat hulle omstreeks 1750 hier gevestig het met Taung as hoofkwartier.

Wat fossiele betref, het hierdie terrein reeds so vroeg as 1919 fossiele bobbejaanskedels opgelewer, ongeveer 100 in aantal. Sommige was van die uitgestorwe genus Parapapio, wat in die Suid-Afrikaanse museum in Kaapstad bewaar word, en ander van die uitgestorwe spesies van die nog lewende genus Papio. Ook is fossiele soos die volgende gevind: vlermuise, hase, 'n klein jakkals (Vulpes), katte (klein), twee uitgestorwe dassie-spesies e.a.

Met ons aankoms was daar reeds 'n groot skare van die plaaslike bevolking teenwoordig. Die terrein was goed versorg met 'n piramidetjie van klip gebou, waarop ' $n$ gedenkplaat aangebring is op die presiese plek, soos bereken, waar die skedeltjie ontdek is. Op die gedenkplaat is die volgende woorde aangebring in Engels:

DIE TAUNG-SKEDEL

DIE EERSTE VAN AFRIKA SE GESKENKE VIR DIE STUDIE VAN DIE MENS SE OORSPRONG is uitgegrawe by die steengroef deur $M$. de Bruyn in November 1924

Professor R.A. Dart van die Universiteit van die Witwatersrand maak dit bekend aan die wêreld op 3 Februarie 1925.

DIE MONUMENT IS OPGERIG DEUR DIE UNIVERSITEIT VAN BOPHUTHATSWANA EN ONTHUL DEUR SY EKSELLENSIE, DR. LUCAS MANYANE MANGOPE, PRESIDENT VAN DIE REPUBLIEK VAN BOPHUTHATSWANA, BY GELEENTHEID VAN DIE INTERNASIONALE TAUNG-DIAMANTJUBILEUM-SIMPOSIUM 3 FEBRUARIE 1985. 